\title{
Energy Savings from GSA's National Deep Energy Retrofit Program
}

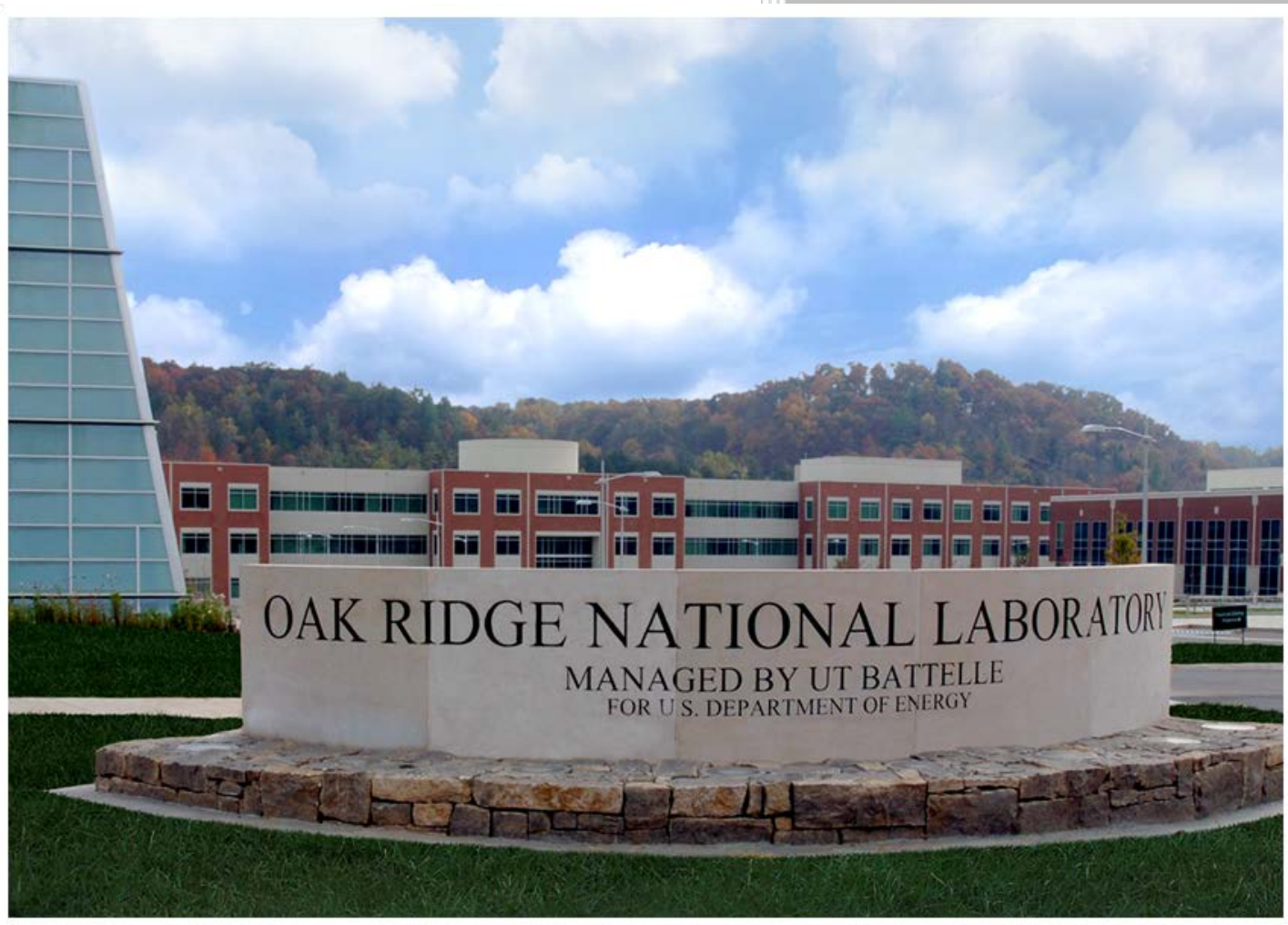

John Shonder

September 2014

Approved for public release: distribution is unlimited. 


\section{DOCUMENT AVAILABILITY}

Reports produced after January 1, 1996, are generally available free via US Department of Energy (DOE) SciTech Connect.

Website http://www.osti.gov/scitech/

Reports produced before January 1, 1996, may be purchased by members of the public from the following source:

National Technical Information Service

5285 Port Royal Road

Springfield, VA 22161

Telephone 703-605-6000 (1-800-553-6847)

TDD 703-487-4639

Fax 703-605-6900

E-mail info@ntis.gov

Website http://www.ntis.gov/help/ordermethods.aspx

Reports are available to DOE employees, DOE contractors, Energy Technology Data Exchange representatives, and International Nuclear Information System representatives from the following source:

Office of Scientific and Technical Information

PO Box 62

Oak Ridge, TN 37831

Telephone 865-576-8401

Fax 865-576-5728

E-mail reports@osti.gov

Website http://www.osti.gov/contact.html

This report was prepared as an account of work sponsored by an agency of the United States Government. Neither the United States Government nor any agency thereof, nor any of their employees, makes any warranty, express or implied, or assumes any legal liability or responsibility for the accuracy, completeness, or usefulness of any information, apparatus, product, or process disclosed, or represents that its use would not infringe privately owned rights. Reference herein to any specific commercial product, process, or service by trade name, trademark, manufacturer, or otherwise, does not necessarily constitute or imply its endorsement, recommendation, or favoring by the United States Government or any agency thereof. The views and opinions of authors expressed herein do not necessarily state or reflect those of the United States Government or any agency thereof. 
Energy and Transportation Science Division

\title{
ENERGY SAVINGS FROM GSA'S NATIONAL DEEP ENERGY RETROFIT PROGRAM
}

\author{
John Shonder \\ Research Staff Member
}

Date Published: September 2014

Prepared by

OAK RIDGE NATIONAL LABORATORY

Oak Ridge, Tennessee 37831-6283

managed by

UT-BATTELLE, LLC

for the

US DEPARTMENT OF ENERGY

under contract DE-AC05-00OR22725 



\section{CONTENTS}

\section{Page}

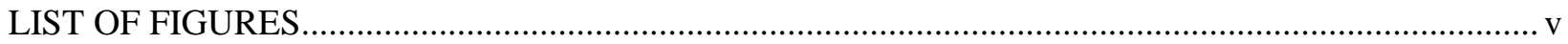

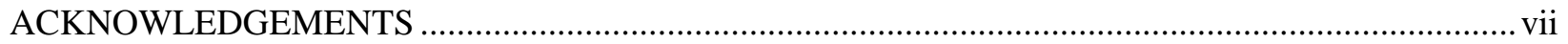

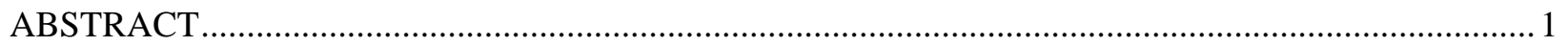

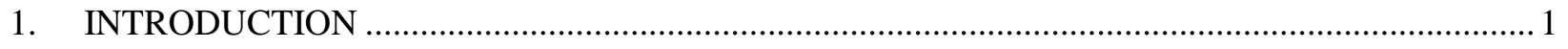

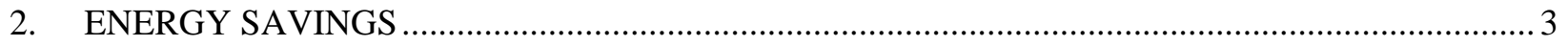

2.1 COMPARISON WITH OTHER FEDERAL ESPC PROJECTS …................................... 3

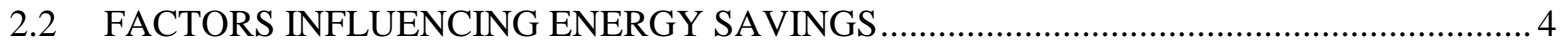

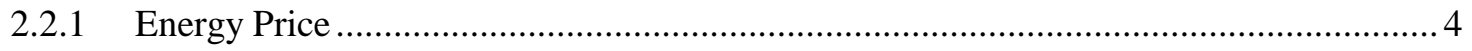

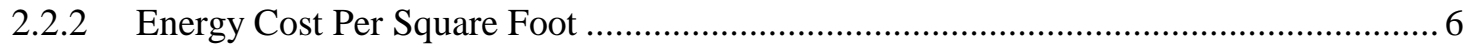

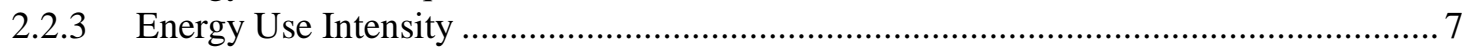

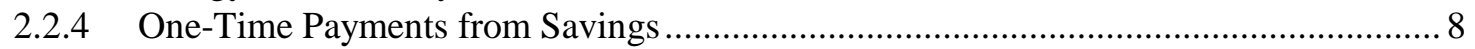

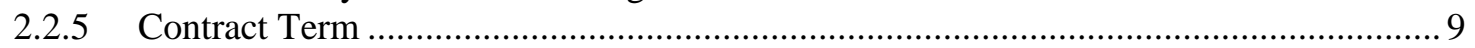

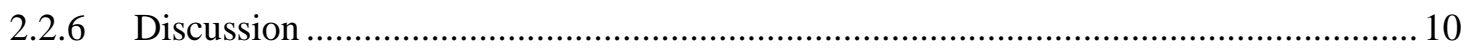

2.3 RATIO OF ENERGY SAVINGS TO INVESTMENT PRICE ........................................... 10

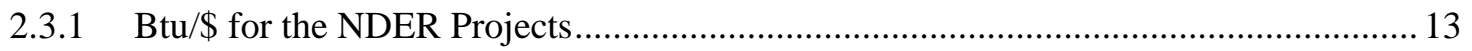

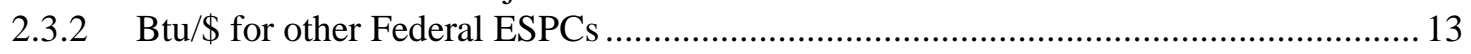

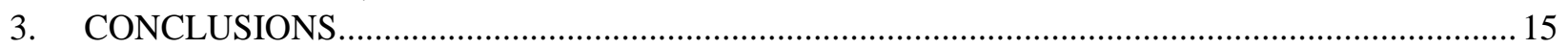

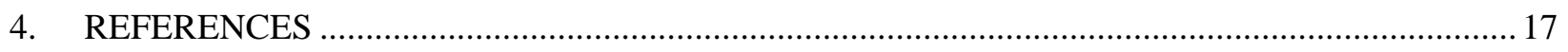

APPENDIX A. GSA NATIONAL DEEP ENERGY RETROFIT TASK ORDERS ….......................... A-1

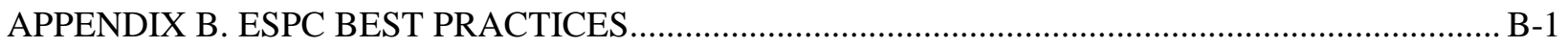





\section{LIST OF FIGURES}

Figure $\quad$ Page

Fig. 1. Percent energy reduction of NDER projects and other recent Federal ESPC projects...................... 4

Fig. 2. Percent savings vs. energy price for NDER projects.................................................................... 5

Fig. 3. Percent savings vs. energy price for NDER projects, excluding the net zero project........................ 5

Fig. 4. Percent energy savings vs. energy cost for NDER projects......................................................... 6

Fig. 5. Percent energy savings vs. energy cost for NDER projects, excluding the net zero project............... 7

Fig. 6. Percent energy savings vs. pre-retrofit EUI for NDER projects................................................. 8

Fig. 7. Percent energy savings vs. percent of investment applied as one-time payment from savings

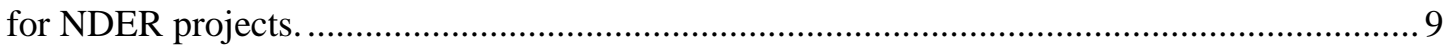

Fig. 8. Percent energy savings vs. project term for the NDER projects.................................................... 10

Fig. 9. Percent total savings vs. percent total investment for \$8.9 million in ECMs from FEMP's

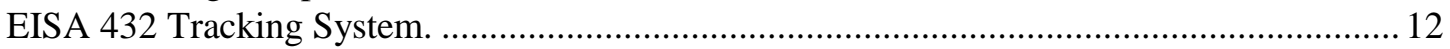

Fig. 10. Simple payback vs. percent energy savings for ECMs in FEMP's EISA 432 Compliance Tracking System, assuming aggregate simple payback of all measures is 30 years and energy costs are \$34.03 per million Btu.............................................................................. 12

Fig. 11. Annual Btu savings per dollar invested vs. percent energy savings for NDER projects ................ 13

Fig. 12. Btu/\$ vs. percent energy savings for the NDER projects and other recent Federal ESPC projects. 



\section{ACKNOWLEDGEMENTS}

The author would like to thank Kinga Porst and Sharon Conger of the US General Services Administration for their support and guidance in the preparation of this document, and their feedback on drafts and earlier presentations made using the data. 



\begin{abstract}
Under its National Deep Energy Retrofit (NDER) program, the U.S. General Services Administration (GSA) awarded ten ESPC projects with the objectives of using innovative technologies and renewable energy technologies, and moving buildings toward net zero energy consumption. This report analyzes data on energy savings from the ten NDER projects, and compares them with the savings of a sample of other recently awarded Federal ESPC projects. It is shown that by emphasizing the need for deeper energy savings, and by establishing a central Project Management Office (PMO) to provide authoritative contracting, technical, and pricing assistance, the NDER projects achieved an average level of savings more than twice that of the other Federal ESPC projects. The level of savings achieved in each project seems to be dependent more on the availability of ECMs at the site than on energy price, energy cost per square foot, pre-retrofit energy use intensity or the length of the contract term. This suggests that GSA can achieve similar results in a wide variety of buildings.
\end{abstract}

\title{
1. INTRODUCTION
}

On March 20, 2012, the US General Services Administration (GSA) issued a Notice of Opportunity (NOO) for a nationwide deep energy retrofit (NDER) program to the 16 energy services companies (ESCOs) associated with the Department of Energy's (DOE's) indefinite-delivery, indefinite quantity (IDIQ) energy savings performance contract (ESPC). The NOO included a list of 30 GSA-owned buildings covering a total occupied area of 16.9 million square feet in 29 states and the U.S. Virgin Islands. Among the objectives for the project were the following:

- Retrofit plans that move a building toward net zero energy consumption

- Use of innovative technologies

- Use of renewable energy technologies

In issuing the NOO, GSA was responding to a number of specific Federal goals:

- The Energy Independence and Security Act of 2007, which requires each Federal Agency to reduce its energy use intensity (site energy use per gross square foot) by 30\% by 2015, compared with a 2003 baseline

- Executive Order 13423, which requires Agencies to reduce water use intensity by $16 \%$ by 2015 , compared with a 2007 baseline

- The Energy Policy Act of 2005, which requires that 7.5\% of the Federal Government's electrical energy use come from renewable energy sources

- President Obama's challenge for Federal Agencies to enter into a combined \$2 billion in performancebased contracts by December 31, 2014

The NDER began with a design charette in October 2011 hosted by GSA's Office of Federal High Performance Green Buildings (OFHPGB) and facilitated by the Rocky Mountain Institute (RMI). The charette brought together ESCOs and staff from GSA's regional and headquarters organizations, DOE's Federal Energy Management Program (FEMP), DOE National Laboratories, and the Department of Defense (DOD) to examine ways to modify and expand the ESPC process to obtain deeper energy savings. The initial charette, and other meetings that followed, sent a strong signal to both ESCOs and 
GSA staff that the NDER was seeking more innovative retrofit projects than had been implemented by ESCOs in the past.

A major recommendation from the initial charette was for GSA to standardize and centralize the ESPC award process, which in the past had been managed by individual GSA regions. An important innovation in the NDER was establishing a Project Management Office (PMO). The PMO established a common timeline for the award process, and provided guidance to regional offices on pricing, financing, engineering, and contracting.

GSA ultimately awarded ten ESPC Task orders with a total value of \$172 million distributed among seven ESCOs. Appendix A presents basic information on each project as extracted from the schedules included in the award. This initial round of the NDER project covers a total of 14.7 million square feet of space in 23 buildings. It will reduce GSA's energy consumption by 365 billion Btu per year, resulting in a first-year guaranteed cost savings of $\$ 10.8$ million, which will be used to pay pack the investment over time. A key result from the project was the average $38.2 \%$ proposed energy savings ${ }^{1}$ over the baselines, which is more than double the average proposed energy savings in a sample of 80 other recent federal ESPC awards.

Through establishing the PMO, GSA also achieved a significant reduction in project cycle time, awarding the ten NDER Task orders in an average of 15.9 months (after ESCO selection) compared with an average of 20.9 months for other projects awarded in response to the President's challenge.

The objectives of this report are to document the results of the NDER projects and how they were achieved, and to compare the results with other recently awarded Federal ESPC projects.

\footnotetext{
${ }^{1}$ It should be noted that energy savings figures presented in this report are as proposed by the ESCOs in the final proposal for each project. When writing is report, all ten projects were still under construction and no field measurements of savings had yet been made.
} 


\section{ENERGY SAVINGS}

\subsection{COMPARISON WITH OTHER FEDERAL ESPC PROJECTS}

A primary motivation for implementing ESPC projects in Federal buildings is the need to meet the goal set in the Energy Independence and Security Act of 2007, which requires each Federal Agency to reduce its energy use intensity (EUI) by 30\% by 2015, compared with a 2003 baseline. Determining the change in EUI resulting from a Federal ESPC project is often problematic. Federal ESPCs usually focus on subsets of buildings at large multibuilding facilities such as military bases, health care facilities, and prisons. Since metered energy use data from individual buildings at these sites is rarely available, measurement and verification of savings is achieved through retrofit isolation methods, i.e., Option A and B techniques according to the terminology of the International Performance Measurement and Verification Protocol (EVO, 2012). ESCOs are required to report baseline energy use and savings in project task order schedules, but the baseline usually refers to the energy use of the equipment being replaced, in which case the baseline energy use of the individual buildings is not reported.

For comparison with the NDER projects, ORNL obtained data from 86 other recently awarded federal ESPC projects, including percent energy savings. All data was as reported by the Agency or the ESCO. For the purposes of this analysis, projects reporting zero or negative energy savings were eliminated. It was unclear whether the zeroes represented projects with no energy savings, or whether the Agency in question was simply unable to report the percent energy savings. As for the negative numbers, it is possible for an energy conservation project to result in negative energy savings, depending on how savings is calculated. For example, a combined heating and power project reduces the use of purchased electricity, but increases the use of purchased natural gas. ESPC task order schedules require energy savings to be calculated on a site energy basis, and when avoided purchased electricity is converted to Btu, the figure is generally less than the Btu increase due to purchased natural gas, resulting in an increase in site energy use (though there is a reduction when calculated on a source energy basis). Executive Order 13123 allows Agencies to take a credit for cost-effective projects where source energy use declines but site energy use increases, but making this correction would mix site and source energy and complicate the analysis. Eliminating the zeroes and negative values left 80 projects in all.

Figure 1 presents the percent energy savings from the NDER and other recent projects in the form of a paired scatter plot. The points are jittered slightly in the vertical direction to avoid overprinting. The mean savings of the ten NDER projects is $38.2 \%$, while the mean savings of the other 80 projects is found to be $19.0 \%$. While it appears from the figure that the distribution of the other Federal projects is skewed more toward the lower end of the scale than the NDER projects, the number of NDER projects is small relative to the others. A statistical test is required to determine whether there is evidence to support the hypothesis that the two groups of projects come from different distributions.

One method of determining whether there is a statistically significant difference between the distributions of two data sets is the Mann-Whitley test. This is a non-parametric test that makes no assumption as to the distribution of the data. Applying this test to the data of Fig. 1 results in a p-value of 0.0026, meaning it is very unlikely that the NDER projects and the other recent Federal projects have the same distribution. The NDER clearly did result in energy savings that were higher, on average, than the savings obtained in other ESPC projects. 


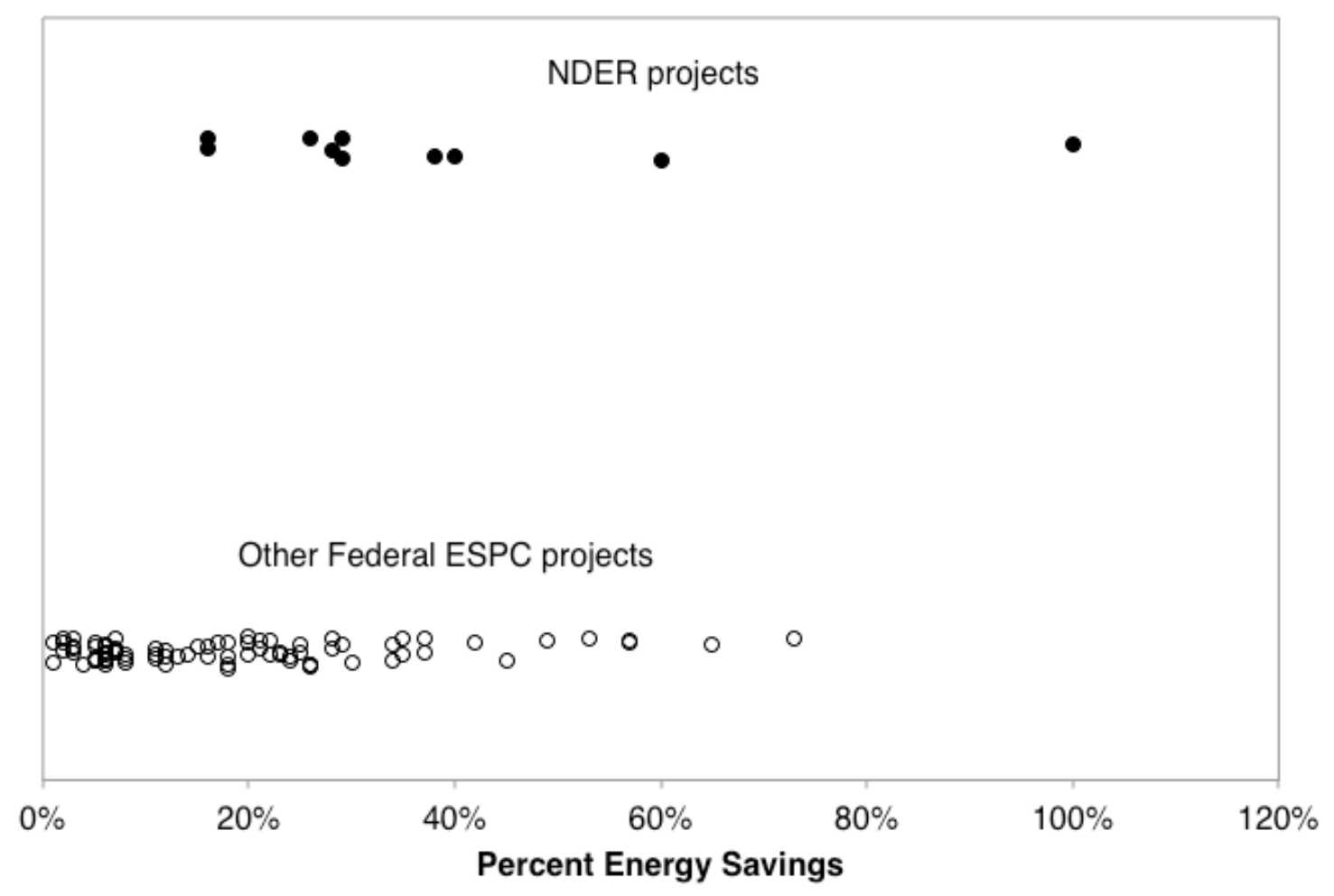

Fig. 1. Percent energy reduction of NDER projects and other recent Federal ESPC projects.

\subsection{FACTORS INFLUENCING ENERGY SAVINGS}

While the NDER projects have higher average energy savings, the level of savings proposed for individual projects ranges from $18 \%$ to $100 \%$. This section examines a number of factors that typically affect energy savings in ESPC projects to determine their influence on the energy savings proposed for the individual NDER projects.

\subsubsection{Energy Price}

An ESPC project must pay for itself (and any performance period services performed by the ESCO) from the cost savings generated by the installed energy conservation measures (ECMs) within the term of the contract. Thus all other things being equal, one would expect higher energy prices to result in deeper energy savings. Higher energy prices make savings more valuable, permitting larger up-front investment in ECMs.

Figure 2 is a plot of percent savings vs. energy price (\$/MMBtu) for the ten NDER projects. Higher energy prices do seem to be associated with higher savings, but this perception is heavily influenced by the net zero project at the Almeric Christian Federal Center. When this project is excluded, as in Fig. 3, the trend line is still in the expected direction - with higher energy prices being associated with higher savings - but the slope of the line is not statistically significant. Evidently, energy price was not a major factor in the level of energy savings proposed for the NDER projects. 


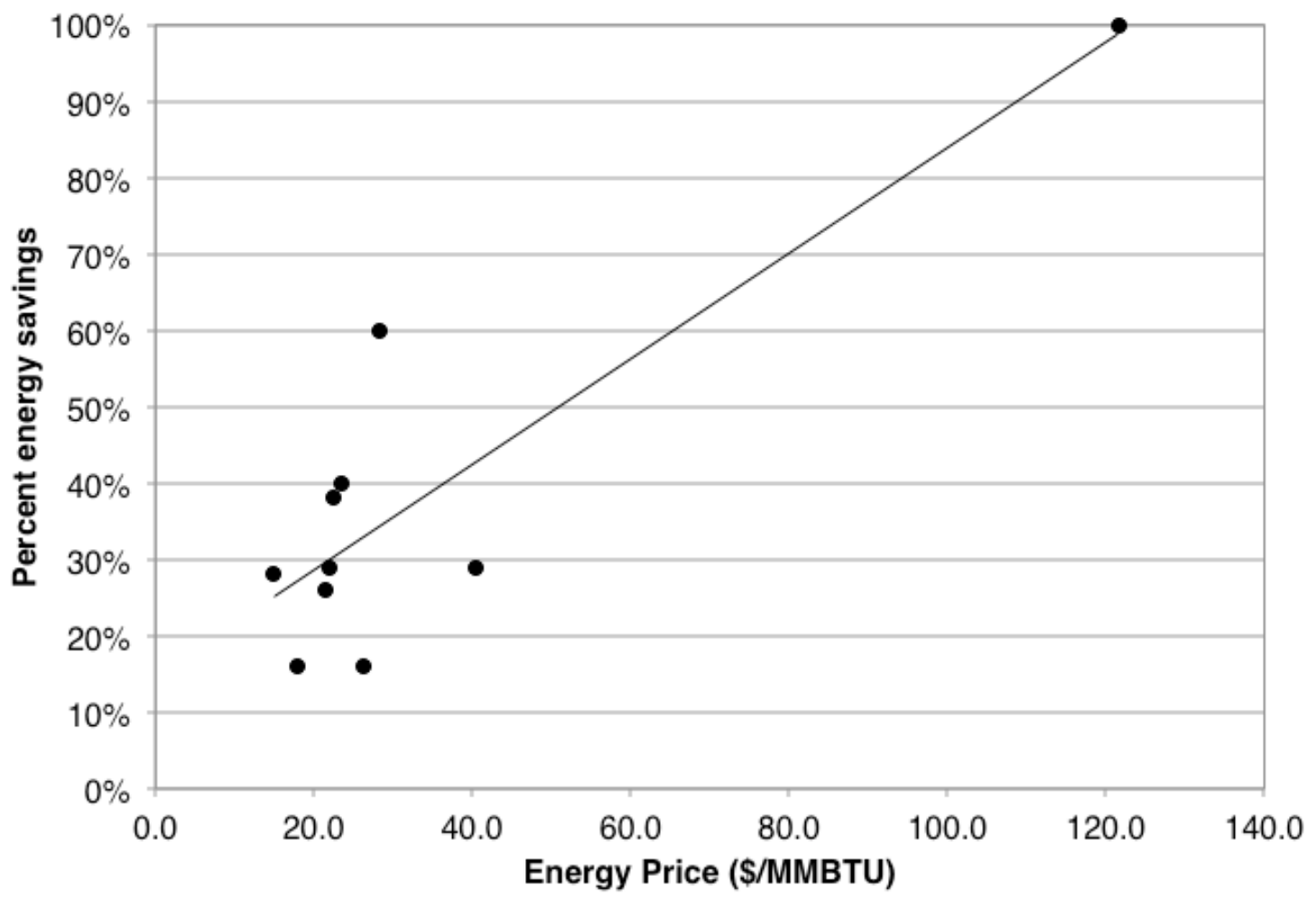

Fig. 2. Percent savings vs. energy price for NDER projects.

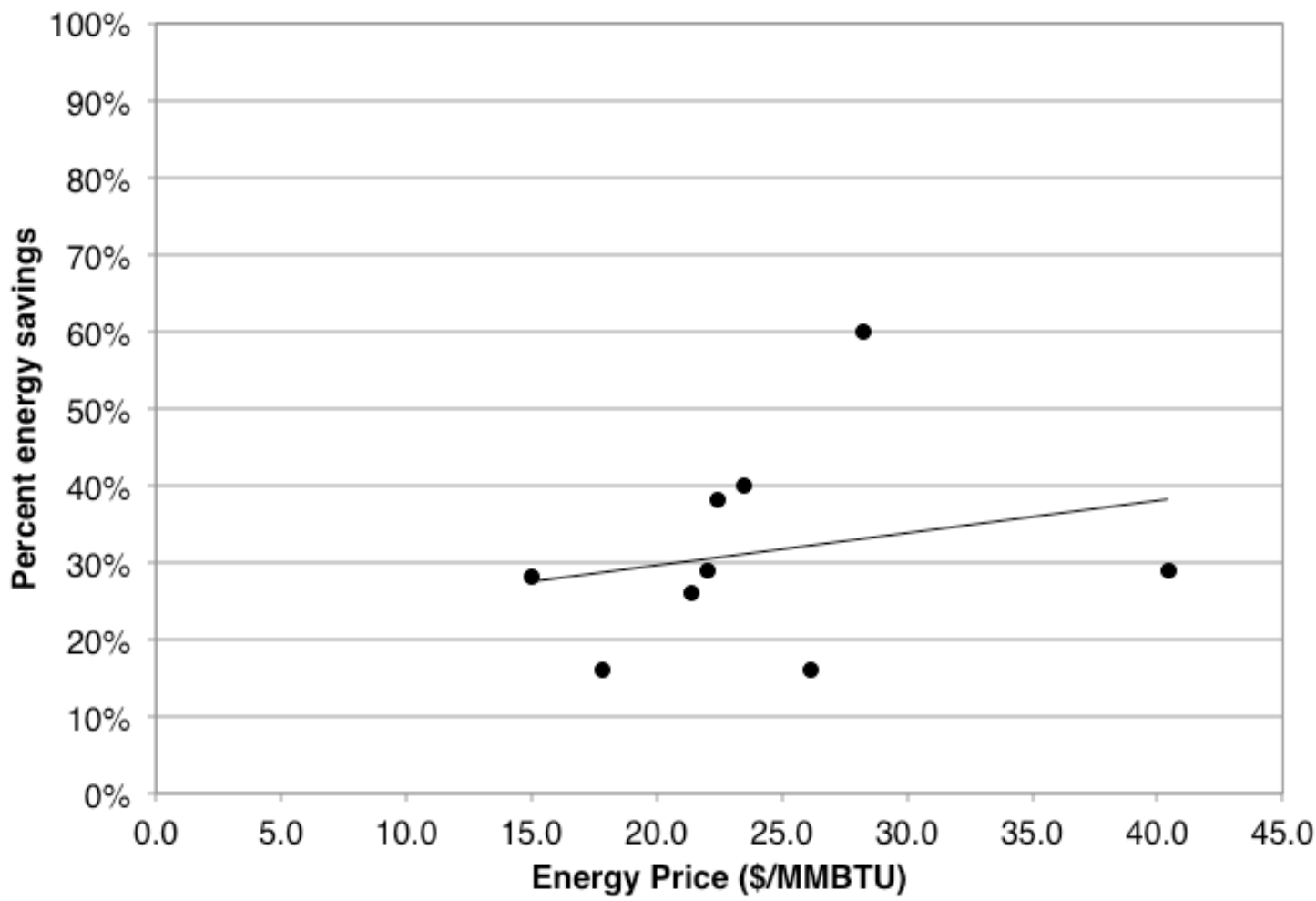

Fig. 3. Percent savings vs. energy price for NDER projects, excluding the net zero project. 


\subsubsection{Energy Cost Per Square Foot}

Another factor that could be expected to influence energy savings is energy cost per square foot. Even with similar energy prices, a building with higher energy cost per square foot might present more opportunities for savings than a building with lower energy cost per square foot, allowing higher investment in ECMs, which could increase the percentage of energy savings over the baseline.

Figure 4 presents the percent energy savings vs. energy cost (\$/square foot) for the ten NDER projects. As with energy price, higher energy costs do appear to result in higher energy savings, but this perception is again influenced by the net zero project. With this project removed, as in Fig. 5, there appears to be no relation. In fact the trend line is in the opposite direction, with percent energy savings decreasing with increasing energy costs. However, the slope is not statistically significant. Energy cost per square foot was not a significant factor in the level of energy savings proposed for the NDER projects.

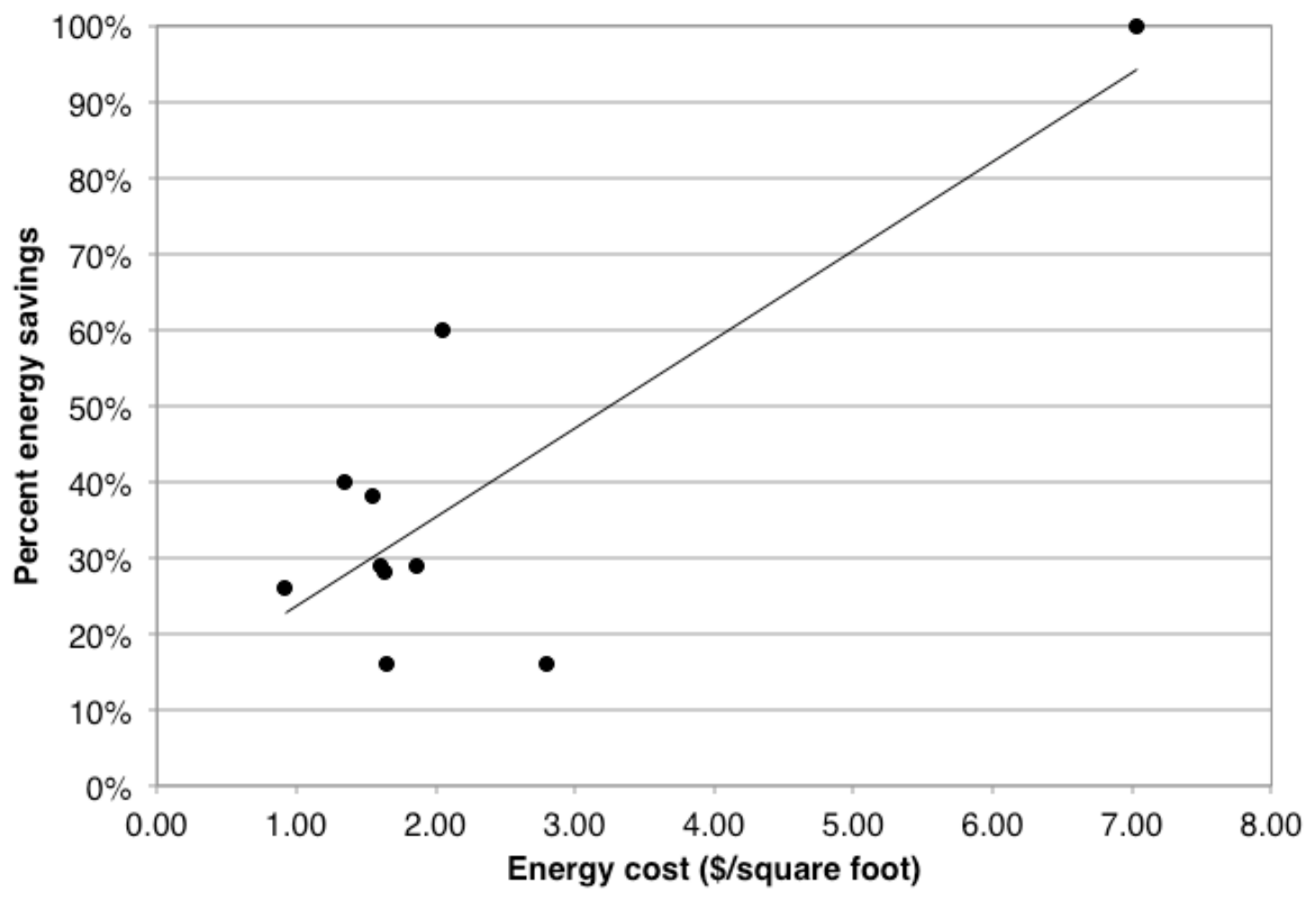

Fig. 4. Percent energy savings vs. energy cost for NDER projects. 


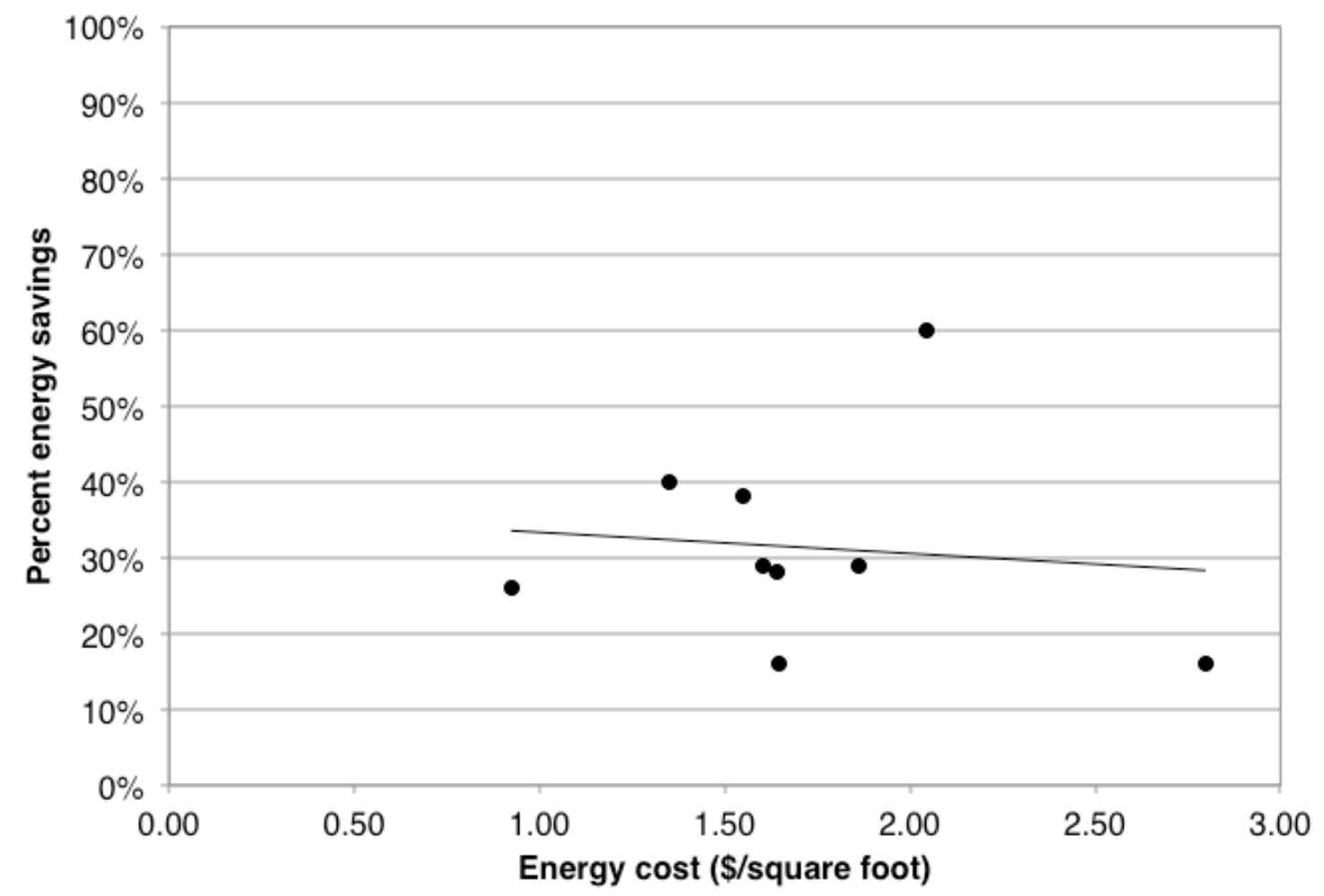

Fig. 5. Percent energy savings vs. energy cost for NDER projects, excluding the net zero project.

\subsubsection{Energy Use Intensity}

All other things being equal, buildings with higher EUI could be expected to present more savings opportunities than buildings with lower EUI, resulting in higher percent energy savings from ESPC projects. Of course EUI is affected by factors such as climate and building function. For the most part the buildings included in the NDER project are all government office buildings and courthouses. They are located in ASHRAE climate zones 1A, 2A, 3A, 4A, 5A, and 6A. However, since DOE benchmarks for medium office buildings in these zones vary only from 39 to 54 Btu per square foot $^{2}$, climate is not the overriding factor in energy use.

Figure 6 presents the percent energy savings from the NDER projects vs. pre-retrofit EUI. The trend line is in fact in the direction opposite of that expected, with higher EUI associated with lower percent energy savings. However, the slope of the line is not significant. Thus pre-retrofit EUI is not a significant factor in the percent energy savings proposed for these buildings either.

\footnotetext{
${ }^{2}$ http://cms.ashrae.biz/EUI/
} 


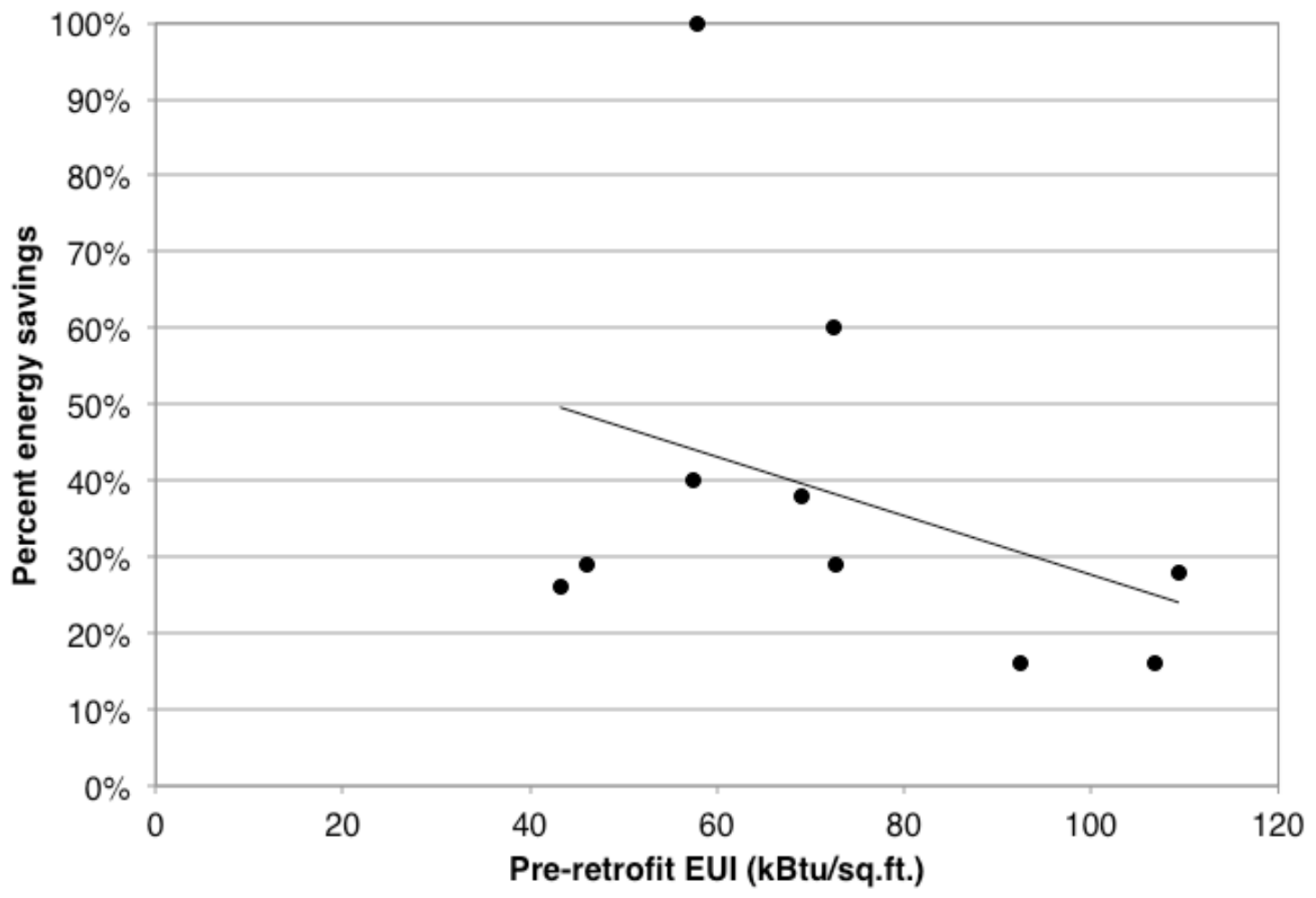

Fig. 6. Percent energy savings vs. pre-retrofit EUI for NDER projects.

\subsubsection{One-Time Payments from Savings}

The availability of one-time payments from savings is another factor that could affect the level of savings achieved. One-time payments improve the economics of ESPC projects, allowing more energy conservation measures to be included, which could result in higher savings. However, as shown in Fig. 7, this was not the case for the ten GSA NDER projects. Percent energy savings is unrelated to the percentage of the total investment that was made available to the ESCO as a one-time payment from savings. 


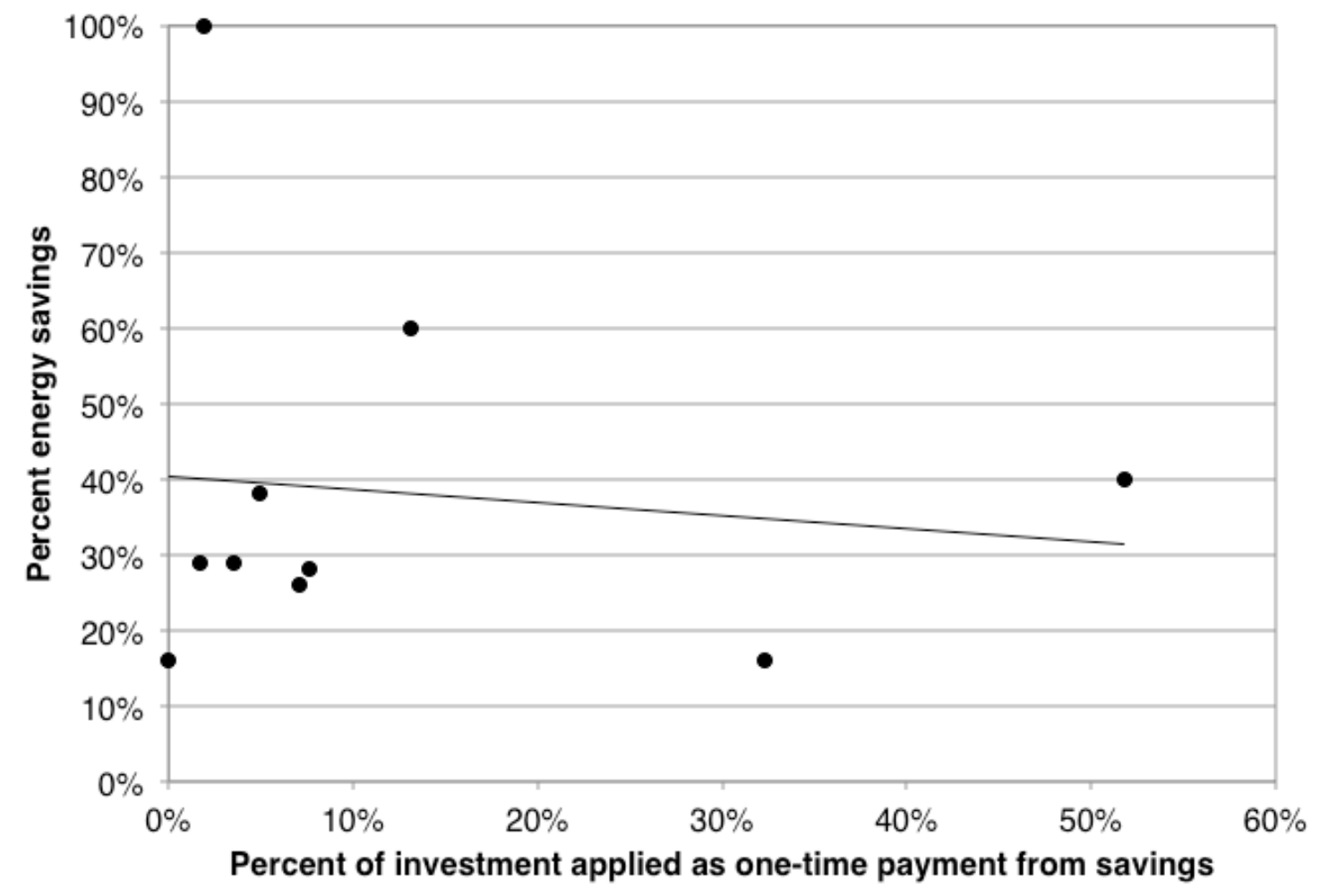

Fig. 7. Percent energy savings vs. percent of investment applied as one-time payment from savings for NDER projects.

\subsubsection{Contract Term}

Appendix A shows that the post-acceptance performance periods (i.e., contract terms) for the ten NDER projects vary from 12 to 23 years. All other things being equal, a longer contract term should drive deeper energy savings, since it allows additional investment in ECMs. While contract term is affected by all of the factors mentioned up to this point, it does depend to some extent on the preference of the Agency, and on the preference of the regional and site personnel who approved the task order.

Figure 8 presents the percent energy savings for the NDER project vs. their contract term. As with the other factors, there is no relation between percent energy savings and contract term. The trend line is again in the direction opposite to that expected, with longer terms associated with lower percent energy savings. However, as before, the slope of this line is not significant. 


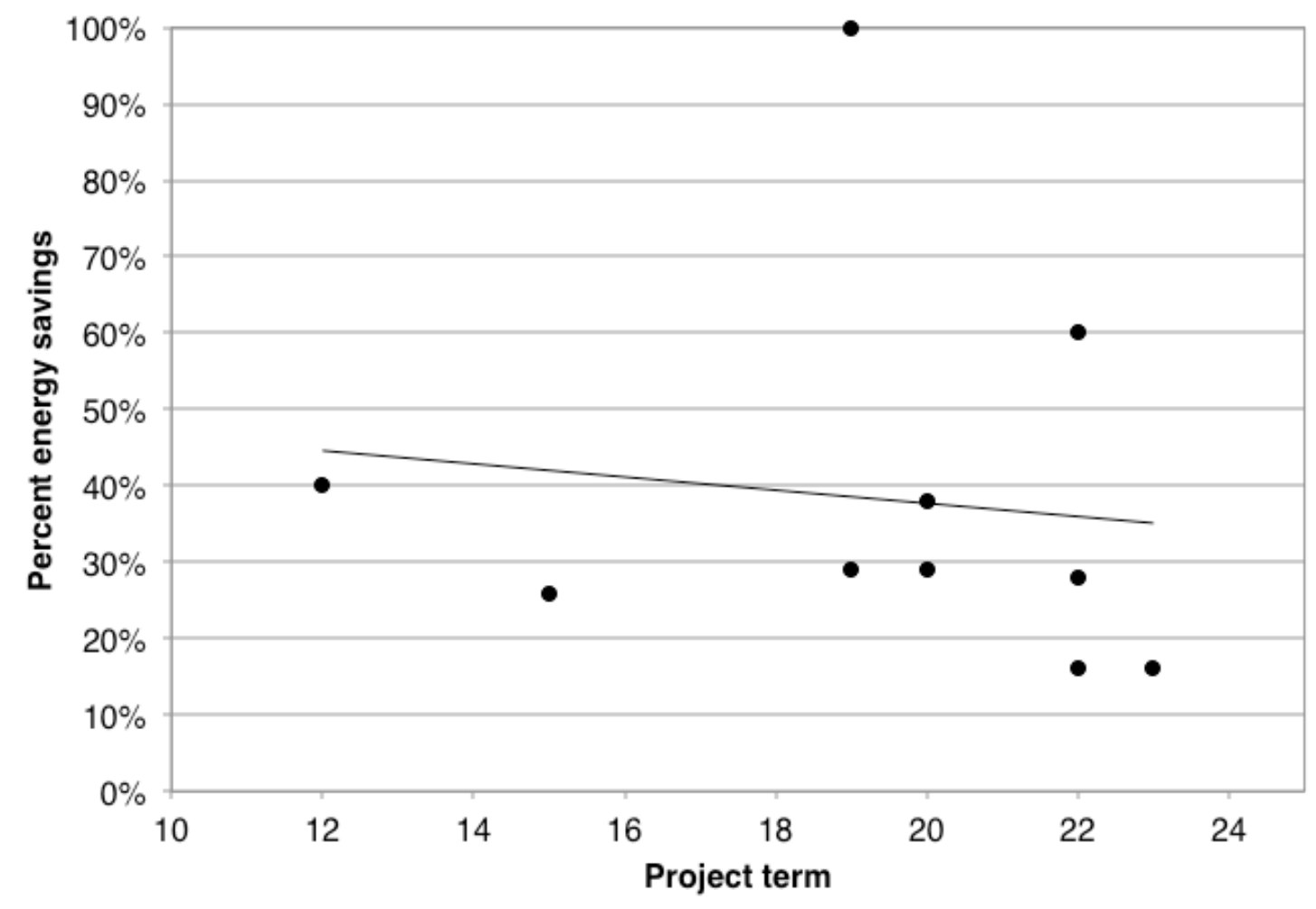

Fig. 8. Percent energy savings vs. project term for the NDER projects.

\subsubsection{Discussion}

It seems logical that deeper energy savings in ESPC would be achieved in projects with the most favorable economics. However, except for the Almeric Christian Federal Building in St. Croix, which has very high energy prices and is slated to achieve net zero energy use, the level of energy savings proposed for the individual NDER projects did not depend on site energy prices or site energy cost per square foot. Furthermore there was no dependence on the energy intensity of the building, the availability of one-time payments from savings, or the length of the project term. Admittedly this is a small number of projects from which to draw conclusions, but it seems that the main factors affecting the level of energy savings achievable are the availability of ECMs and the ESCO's ability to identify them and combine them into a feasible project with a term within the statutory maximum of 25 years. This implies that deep energy savings may be available in a wide variety of GSA buildings.

\subsection{RATIO OF ENERGY SAVINGS TO INVESTMENT PRICE}

Since the Federal government seeks to maximize energy savings and minimize project costs, one measure of the effectiveness of an ESPC project is the ratio of annual energy savings in Btu's to project investment price. Note that if the guaranteed cost savings comes from energy cost savings alone, the following relation holds:

Btu/\$ = 1/(energy price*project simple payback) 
Thus projects with short simple paybacks tend to have higher Btu savings per dollar invested, and vice versa.

The Btu/ $\$$ ratio is not a perfect measure; it is affected by a number of factors including interest rates, the availability of one-time payments from savings, and the availability of savings from other sources such as water and maintenance. In DOE's ESPC IDIQ program, this ratio has varied widely from year to year, but has been trending downward over time, from an average of $8,300 \mathrm{Btu} / \$$ during the first five years of the program to an average of $4,500 \mathrm{Btu} / \$$ over the past five years.

One reason for this decrease may be the declining availability of so-called "low-hanging fruit.” Because of fixed costs embedded in the project development process, ESCOs prefer to implement projects with investment value above a threshold in the neighborhood of \$2-\$3 million. During the early years of the ESPC program, Federal buildings were likely much less efficient, and ESCOs were able to assemble sufficiently large projects with lighting upgrades, simple controls, and other short-payback ECMs only. Projects overall had shorter aggregate simple paybacks and correspondingly higher Btu/\$ ratios. Now that Federal buildings have improved, ESCOs must dig deeper and include longer-payback ECMs to achieve their investment threshold, leading to higher aggregate simple paybacks and lower Btu/\$ ratios.

This has implications for deep retrofit projects. Figure 9, reproduced from Shonder (2012), presents the percentage of total savings as a function of percent of total investment for about $\$ 9$ billion in ECMs at Federal sites, as reported to DOE’s EISA Section 432 Compliance Tracking System (CTS) (http://energy.gov/eere/femp/eisa-compliance-tracking-system-reports-and-data). In the figure, the projects are arranged from shortest to longest payback. A similar curve could be developed using the ECMs available at any Federal site. The figure shows, for example, that the $10 \%$ of investment corresponding to the shortest-payback ECMs delivers 35\% of the total cost savings available. Additional investment delivers diminishing returns, however: An additional $10 \%$ of investment increases savings to $54 \%$ of the total, an increment of just $19 \%$.

Using some reasonable assumptions, the curve of Fig. 9 can be transformed to show the relation between percent energy savings and Btu/\$ invested. First, assume that the $100 \%$ cost savings represents net-zero energy, i.e., a 100\% reduction in site energy use. At most locations, achieving net zero has a very long simple payback. Assume this is 30 years. Using an energy price of $\$ 34.30$ per million Btu (the average for the NDER projects) results in the curve of Fig. 10.

Although not intended to be representative of all federal ESPCs, the curve in Fig. 10 does appear to cover the correct range for the Btu/ $\$$ ratio. It shows that in general, projects with deeper energy savings can be expected to save less energy per dollar invested. 


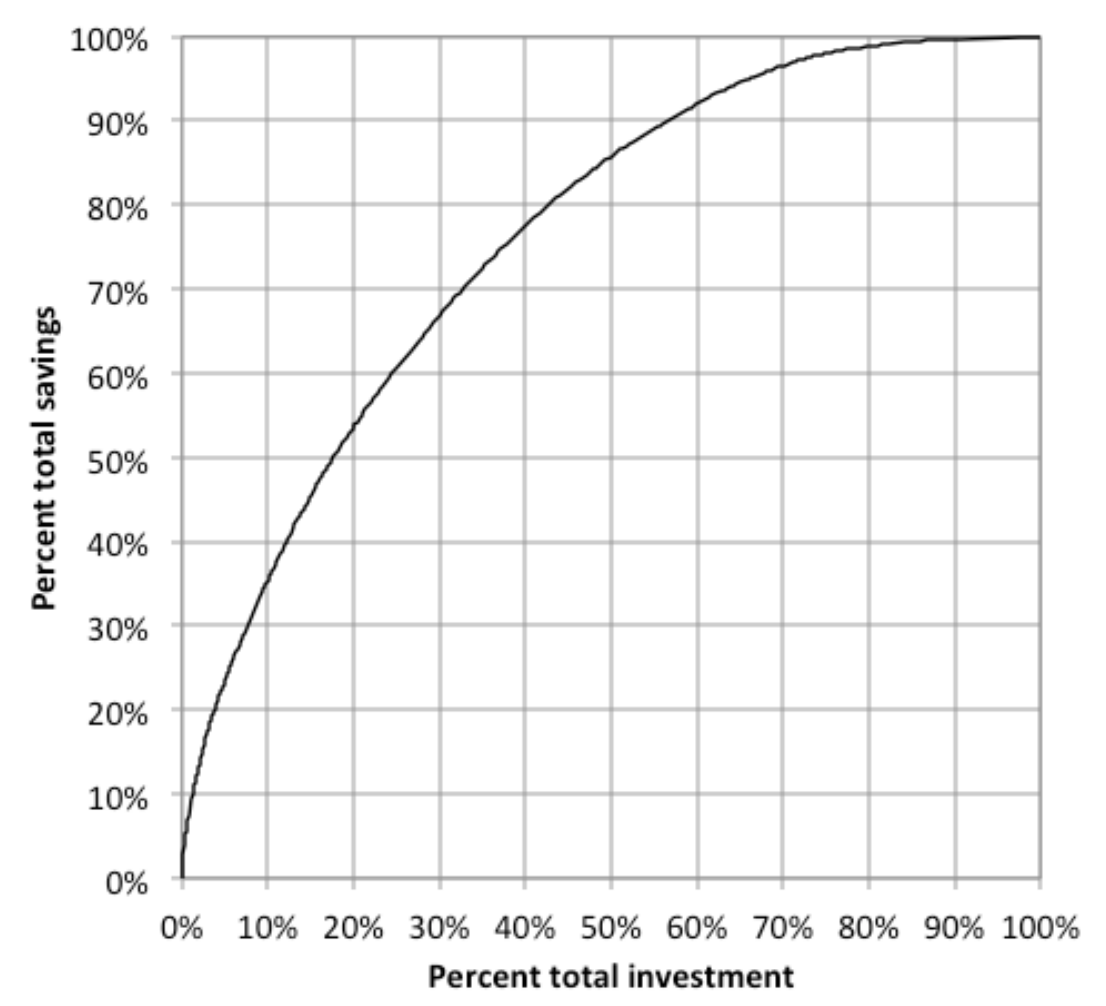

Fig. 9. Percent total savings vs. percent total investment for $\$ 8.9$ million in ECMs from FEMP's EISA 432 Tracking System.

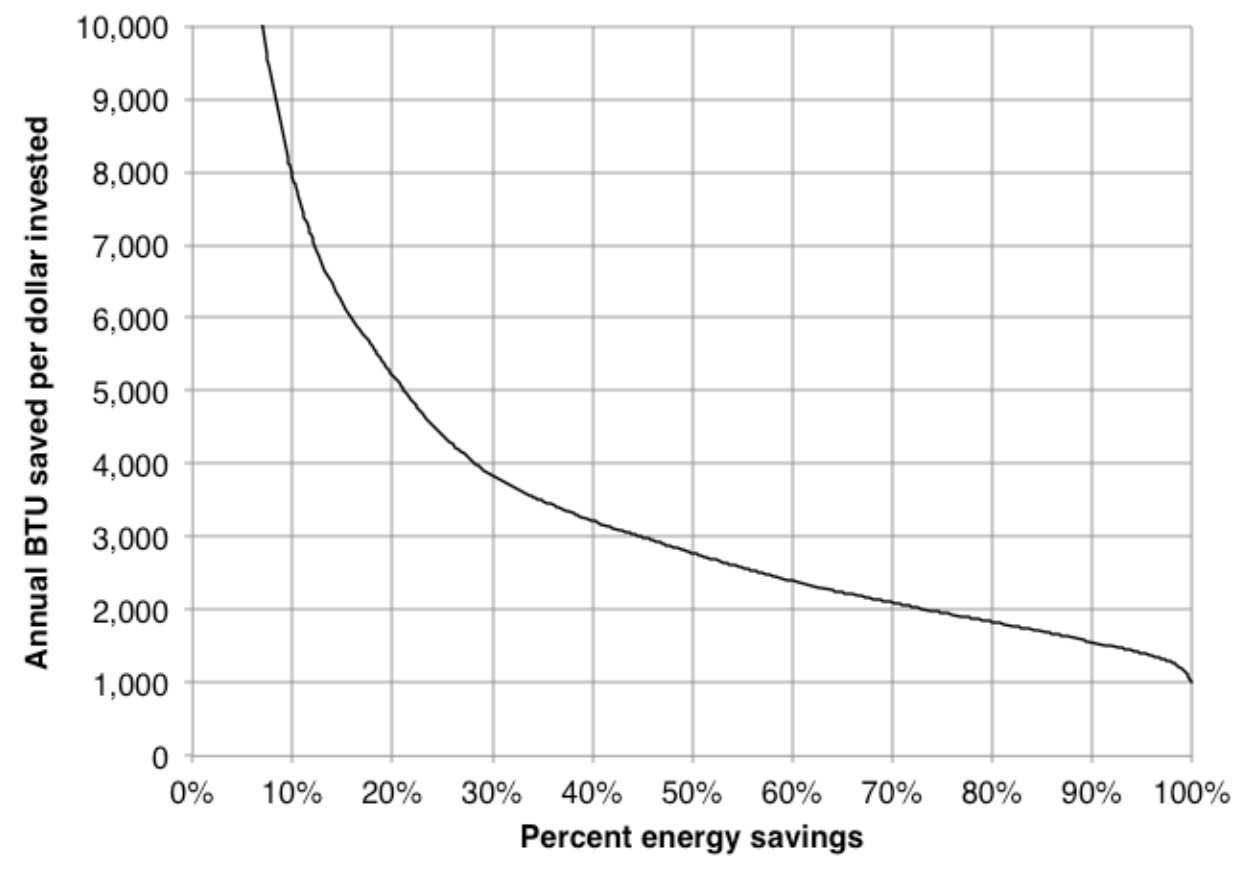

Fig. 10. Simple payback vs. percent energy savings for ECMs in FEMP's EISA 432 Compliance Tracking System, assuming aggregate simple payback of all measures is 30 years and energy costs are $\$ 34.03$ per million Btu. 


\subsubsection{Btu/\$ for the NDER Projects}

Figure 11 overlays the data from the NDER projects on Fig. 10. The projects appear to break into two distinct groups: five projects that lie close to the CTS curve of Btu/\$ vs. percent savings, and five that are well below it. In general, for a given percent energy savings, projects closer to the curve achieve higher energy savings per dollar invested than those lying below the curve.

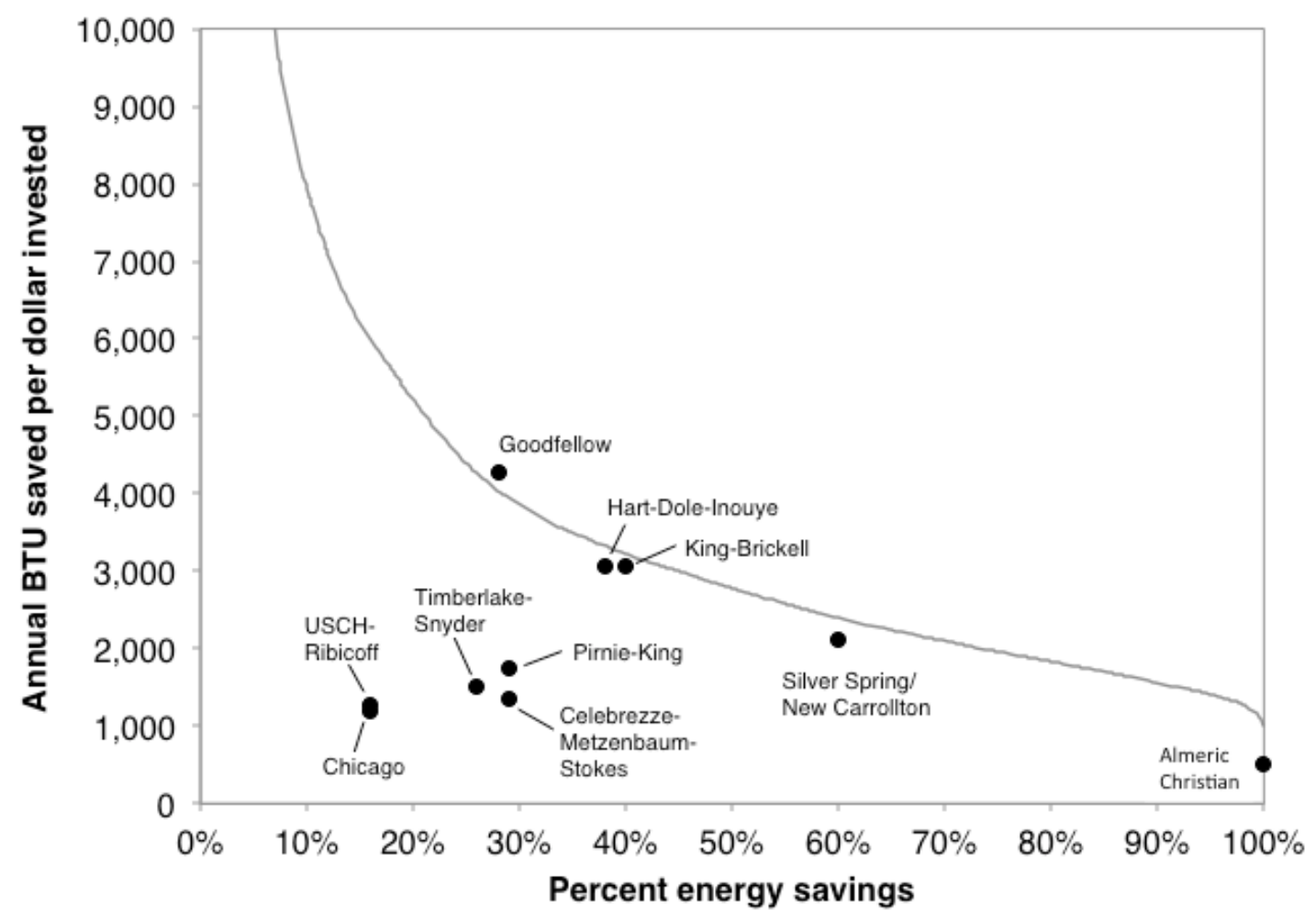

Fig. 11. Annual Btu savings per dollar invested vs. percent energy savings for NDER projects

Examination of the project data provides no clear distinction between the two groups. While the project interest rates varied from $3.14 \%$ to $5 \%$, there is no evidence that projects with lower interest rates achieved higher Btu/\$. In both groups, some projects included substantial up-front payments and others did not. Some projects in both groups included O\&M savings, and some did not. Nor does there seem to be a clear distinction between the types of ECMs installed in the two groups. It may be of interest, however, that three of the five projects with high Btu/\$ (Almeric Christian, Goodfellow, and Silver Spring-New Carrolton) included some type of envelope measure, while only one of the five projects with low Btu/\$ (US Custom House-Ribicoff) included such measures. According to the Rocky Mountain Institute and other practitioners, addressing envelope measures is a key ingredient of a deep retrofit projects. In addition, two of the projects with low Btu/\$ (Chicago and Celebrezze-Metzenbaum-Stokes) included construction of on-site chillers to replace district chilled water service. Cost savings rather than energy savings per se was the primary driver for these ECMs.

\subsubsection{Btu/\$ for other Federal ESPCs}

Figure 12 compares the Btu/\$ and percent energy savings of the NDER projects with those of the other recently awarded Federal ESPC projects. First, it is evident that the majority of the projects fall below the 
CTS curve, including the group of five NDER projects with low Btu/\$. However, it is also seen that seven of the other Federal ESPC projects lie above the CTS curve. Undoubtedly, other factors such as up-front payments and the availability of O\&M savings may be driving the higher values for these projects. It is also possible that the percent energy savings for some of these projects may be in reference to the ECMs themselves, rather than to the baseline energy use of the treated buildings. In the NDER program, GSA required the ESCOs to calculate the percent energy savings with respect to the energy use of the buildings. As mentioned above, this has not been a traditional practice in Federal ESPC, and it may be that some of the data from the other Federal ESPC projects was reported in error.

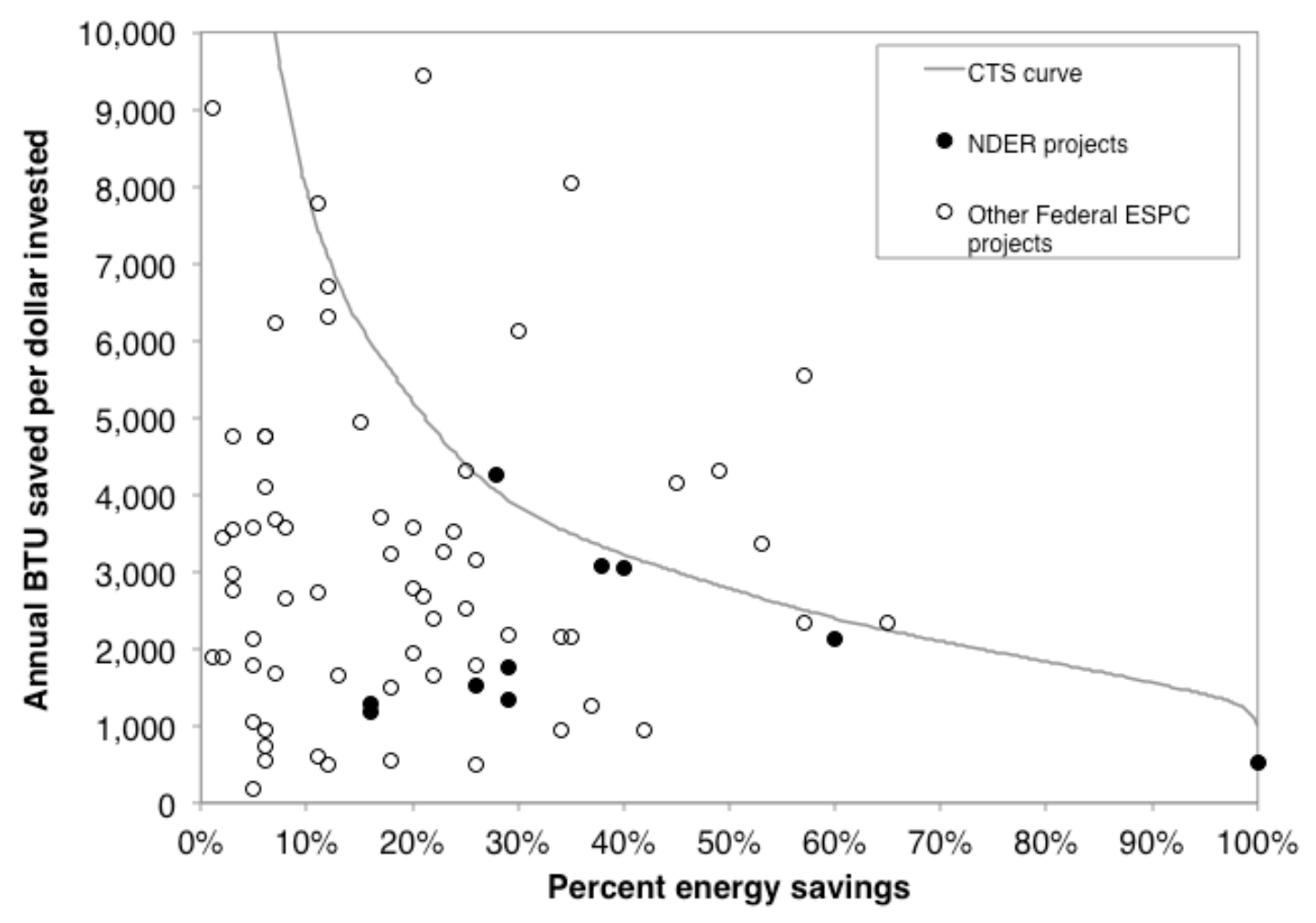

Fig. 12. Btu/\$ vs. percent energy savings for the NDER projects and other recent Federal ESPC projects.

The fact that Btu savings per dollar invested generally decreases with increasing savings is an important result because this ratio is often seen as a measure of the effectiveness of ESPC projects. While GSA and other Federal agencies wish to maximize energy savings and minimize investment costs, experience-based rules of thumb will not apply to projects with higher levels of energy savings. At a given level of energy savings, projects with higher Btu savings per dollar invested are indeed more effective at saving energy, but the comparison breaks down for projects with differing levels of savings. 


\section{CONCLUSIONS}

The main conclusion of this report is that GSA did achieve its goal of obtaining higher energy savings in the NDER program. The average of 38.2\% savings over baseline energy use was more than double the average savings of $19 \%$ seen in a group of 80 recently awarded Federal ESPC projects. The difference in the distributions of the two data sets is statistically significant.

The best results were obtained at the Almeric Christian Federal Building in St. Croix, U.S. Virgin Islands, where very high energy prices - and the correspondingly higher value of the energy savings - permitted higher investment in energy conservation measures, including solar PV, allowing the ESCO to achieve net zero energy use. For energy prices more typical of those seen in the continental U.S., the level of energy savings in the NDER projects was unrelated to energy price. Furthermore, the level of energy savings proposed for individual projects was unrelated to any of the factors one might expect to drive higher savings, including pre-retrofit EUI, the amount of appropriated funding available as a one-time payment from savings, or the length of the post-acceptance performance period.

Energy savings in the NDER projects appears to have been achieved through conventional means: by surveying the facilities to determine energy savings opportunities, and combining the available opportunities into feasible pay-from-savings projects. Factors such as energy price, EUI, and the availability of one-time payments certainly affected project economics at the margin, but the level of savings proposed appears to be more a function of the conservation measures available at each location, and the skill of the ESCOs at identifying them. This suggests that similar levels of energy savings could be available in a wide variety of GSA buildings.

GSA is already using a screening tool to identify potential candidates for ESPC projects. However, aside from the obvious fact that feasible projects are unlikely to be achieved in facilities that were recently upgraded, the results from the NDER program show that there will continue to be a need for ESCOs to travel to project sites and perform energy audits to determine the conservation measures available.

Deeper energy savings do come at a cost, however. The results from the NDER program show that to achieve higher levels of energy savings, ESCOs must invest more per Btu saved. Equivalently, the number of Btu's saved per dollar invested decreases as the percent energy savings increases. The same effect was seen in the data from other recently awarded Federal ESPC projects. This suggests that the ratio of Btu saved to dollar investment is not the best measure of the value of an ESPC project.

The higher average level of savings in the NDER program likely came about because of two factors. First, GSA's announcement of a National Deep Energy Retrofit project and the publicity surrounding it sent a signal to both ESCOs and GSA managers that deeper energy savings were desired. This encouraged ESCOs to dig deeper to find energy savings opportunities, and to include ECMs they might otherwise have expected GSA managers to reject. The design charettes hosted by the Rocky Mountain Institute reinforced this message.

The establishment of the Project Management Office appears to be another factor in obtaining higher energy savings. In the past, GSA regions had a great deal of autonomy in awarding ESPCs, and differing levels of expertise and experience in the regions led to uneven results. By providing a central source of assistance for contracting, technical, and pricing issues, the PMO helped to standardize the ESPC review and award process. A key innovation was the PMO's decision to develop independent government estimates of ECM pricing for each of the NDER projects. Authoritative technical and contracting advice, combined with increased confidence in the pricing received, likely influenced the regions to accept more 
comprehensive projects, leading to correspondingly higher levels of savings. The PMO improved GSA's process in other ways as well, leading to a shorter ESPC development cycle.

Finally, it might be argued that selection bias is another factor in the higher savings achieved in the 10 NDER projects. Certainly, some buildings included at the PA stage were dropped from consideration because ESCOs did not encounter enough cost savings opportunities to develop a feasible ESPC project. For some of the remaining projects, one-time payments from savings were required to achieve feasibility. However, there is no reason to believe that the sample of 80 projects from other federal agencies is any different: since these are all awarded projects, they by definition do not include non-feasible projects. Likewise, one-time payments from savings were used to improve the economics of many of the 80 projects from other agencies. Thus selection bias is likely present in both data sets, and does not seem to be a factor in the higher savings achieved by the NDER projects.

In September 2013, the Commissioner of GSA's Public Buildings Service issued a memo that stated in part:

In order to stretch the limited funds we have, beginning in FY15, we will not fund any renovation projects from direct appropriated funds, if they can be accomplished with an ESPC. ... We intend to use ESPCs and Utility Energy Services Contracts (UESCs) to get the maximum possible improvement to each building as long as it can be amortized over the 25-year potential term of these contracts. Toward that end, we will combine energy conservation measures (ECMs), so that measures with a short payback offset those with a longer payback in order to fully optimize the 25-year potential authority.

The NDER program, and the innovations it put in place, provide a foundation for achieving the Commissioner's goals in future projects. 


\section{REFERENCES}

EVO (Efficiency Valuation Organization), 2007. International Performance Measurement and Verification Protocol: Concepts and Options for Determining Energy and Water Savings, Volume 1. http://evoworld.org/

Shonder, J., 2012. "Mixing Appropriations and Private Financing to Meet Federal Energy Management Goals,’ORNL/TM-2012/235. Oak Ridge National Laboratory, Oak Ridge, TN, June. 



\section{APPENDIX A. GSA NATIONAL DEEP ENERGY RETROFIT TASK ORDERS}

\begin{tabular}{|c|c|c|c|c|c|c|c|c|}
\hline $\begin{array}{c}\text { GSA } \\
\text { Region }\end{array}$ & Building(s) & Location(s) & Conservation Measures & ESCO & Investment & $\begin{array}{c}\text { Term } \\
\text { (years) }\end{array}$ & $\begin{array}{c}\text { Energy } \\
\text { Savings } \\
\text { (MMBtu/yr) }\end{array}$ & $\begin{array}{l}\text { Percent } \\
\text { Energy } \\
\text { Savings }\end{array}$ \\
\hline 1 & $\begin{array}{l}\text { U.S. Custom House- } \\
\text { Ribicoff Federal } \\
\text { Building }\end{array}$ & $\begin{array}{l}\text { New Bedford } \\
\text { MA/Hartford CT }\end{array}$ & $\begin{array}{l}\text { Custom House } \\
\text { Boiler Burner Conversion } \\
\text { Lighting Upgrades } \\
\text { Roof Replacement and Insulation } \\
\quad \text { Upgrade } \\
\text { Ribicoff } \\
\text { Controls Upgrades } \\
\text { Lighting Upgrades } \\
\text { Building Weatherization } \\
\text { Insulate Steam Components } \\
\text { Upgrade to LP Steam Header/Install } \\
\text { Boiler }\end{array}$ & Siemens & $\$ 3,372,681$ & 20 & 4,330 & $16 \%$ \\
\hline 2 & $\begin{array}{l}\text { Pirnie Federal } \\
\text { Center-ML King } \\
\text { Courthouse }\end{array}$ & $\begin{array}{l}\text { Utica } \\
\text { NY/Newark NJ }\end{array}$ & $\begin{array}{l}\text { Pirnie } \\
\text { Upgrade Building Controls } \\
\text { HVAC Improvements } \\
\text { King } \\
\text { Interior and Exterior Lighting } \\
\quad \text { Retrofit } \\
\text { Demand Controlled Ventilation } \\
\text { Heating Reclaiming System } \\
\text { Lighting Upgrades } \\
\text { Lighting Controls }\end{array}$ & Siemens & $\$ 1,853,067$ & 19 & 3,252 & $29 \%$ \\
\hline 2 & $\begin{array}{l}\text { Almeric Christian } \\
\text { Federal Building }\end{array}$ & $\begin{array}{l}\text { St. Croix, Virgin } \\
\text { Islands }\end{array}$ & $\begin{array}{l}\text { Chiller Improvements } \\
\text { BAS Improvements } \\
\text { Replace AHUs 2, } 4 \text { \& } 6 \\
\text { Interior Lighting Improvements } \\
\text { Window Film Installation } \\
\text { VFDs - Variable volume CHW } \\
\text { Distribution } \\
\text { Ground Mounted Solar } \\
\text { Building Transformer Replacement } \\
\text { Retro Commissioning }\end{array}$ & Schneider & $\$ 6,372,000$ & 19 & 3,286 & $100 \%$ \\
\hline
\end{tabular}




\begin{tabular}{|c|c|c|c|c|c|c|c|c|}
\hline $\begin{array}{c}\text { GSA } \\
\text { Region }\end{array}$ & Building(s) & Location(s) & Conservation Measures & ESCO & Investment & $\begin{array}{l}\text { Term } \\
\text { (years) }\end{array}$ & $\begin{array}{c}\text { Energy } \\
\text { Savings } \\
\text { (MMBtu/yr) }\end{array}$ & $\begin{array}{c}\text { Percent } \\
\text { Energy } \\
\text { Savings }\end{array}$ \\
\hline 4 & $\begin{array}{l}\text { King-Brickell } \\
\text { Buildings }\end{array}$ & Miami FL & $\begin{array}{l}\text { Brickell } \\
\text { Pkged. HVAC Equipt. } \\
\text { Lighting Upgrades Lighting } \\
\text { Controls } \\
\text { Water Conservation } \\
\text { King } \\
\text { Water Treatment } \\
\text { Chiller Replacement and Plant } \\
\quad \text { Upgrades } \\
\text { VAV Controls } \\
\text { Lighting Upgrades } \\
\text { Lighting Controls } \\
\text { Water Conservation } \\
\text { Water Treatment }\end{array}$ & FPL & $\$ 4,358,579$ & 12 & 13,317 & $40 \%$ \\
\hline 4 & Timberlake-Snyder & $\begin{array}{l}\text { Tampa } \\
\text { FL/Louisville KY }\end{array}$ & $\begin{array}{l}\text { Timberlake } \\
\text { Lighting Improvements } \\
\text { Chiller Replacement } \\
\text { Variable Flow Pumps } \\
\text { Condenser Water Electronic Filter } \\
\text { Snyder } \\
\text { Chiller Replacement } \\
\text { Lighting Improvements } \\
\text { Condenser Water Electronic Filter }\end{array}$ & Constellation & $\$ 4,251,738$ & 15 & 6,460 & $26 \%$ \\
\hline 5 & $\begin{array}{l}\text { Celebrezze- } \\
\text { Metzenbaum-Stokes }\end{array}$ & Cleveland $\mathrm{OH}$ & $\begin{array}{l}\text { Celebrezze } \\
\text { New Gas Fired Heating Water } \\
\text { Plant: Replace City Steam } \\
\text { New Chilled Water Plant: Replace } \\
\text { City Chilled Water } \\
\text { Upgrade or replacement of existing } \\
\text { EMCS systems } \\
\text { Interior lighting retrofits and } \\
\text { replacements } \\
\text { Exterior lighting retrofits and } \\
\text { replacements } \\
\text { Domestic Water Measures }\end{array}$ & Siemens & $\$ 37,219,112$ & 20 & 49,875 & $29 \%$ \\
\hline
\end{tabular}




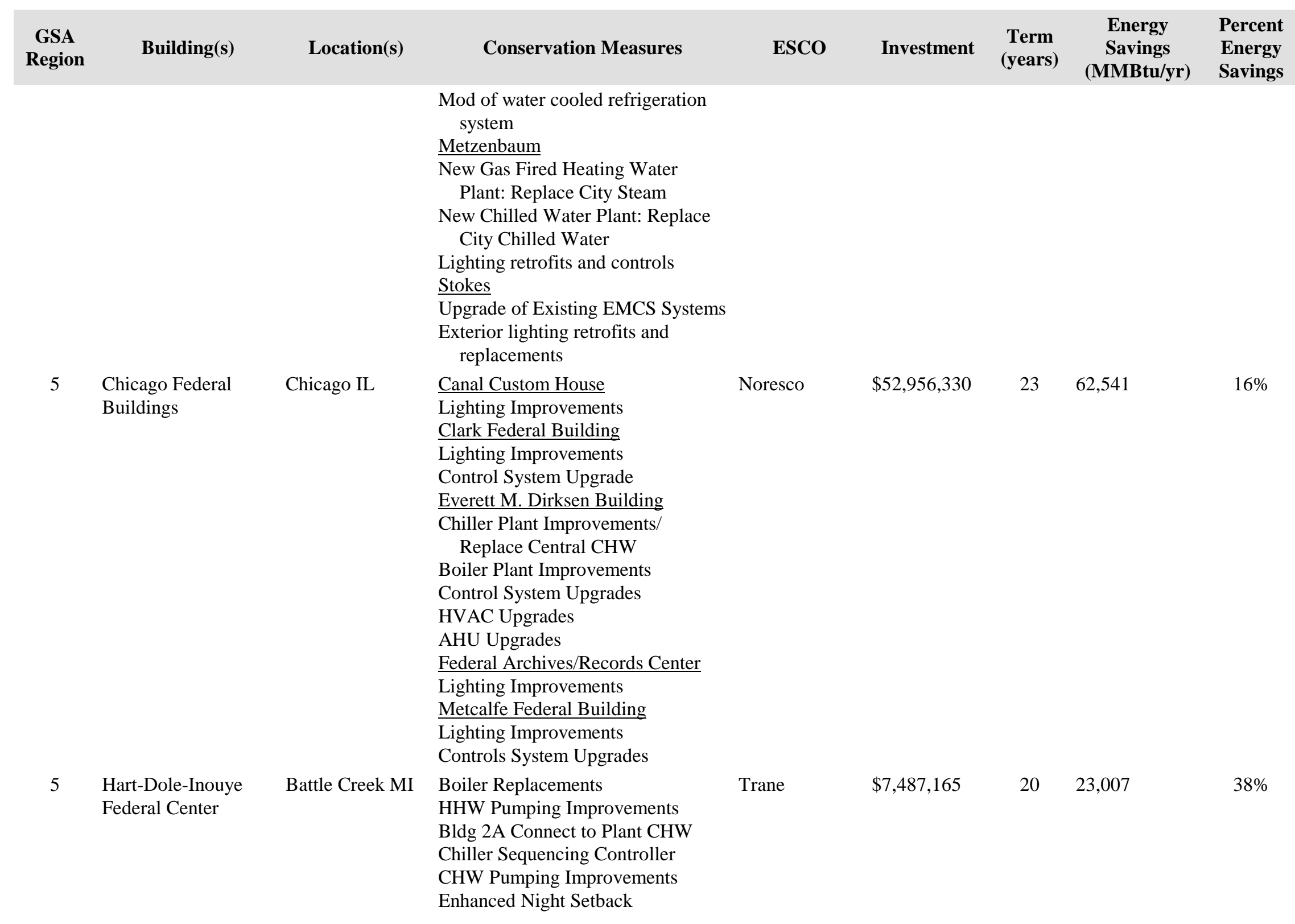




\begin{tabular}{|c|c|c|c|c|c|c|c|c|}
\hline $\begin{array}{c}\text { GSA } \\
\text { Region }\end{array}$ & Building(s) & Location(s) & Conservation Measures & ESCO & Investment & $\begin{array}{c}\text { Term } \\
\text { (years) }\end{array}$ & $\begin{array}{c}\text { Energy } \\
\text { Savings } \\
\text { (MMBtu/yr) }\end{array}$ & $\begin{array}{l}\text { Percent } \\
\text { Energy } \\
\text { Savings }\end{array}$ \\
\hline & & & $\begin{array}{l}\text { Tunnel and Exhaust Dampers } \\
\text { Control Sequence Optimization } \\
\text { Enthalpy Economizer Repair } \\
\text { Bldg 2C Damper \& Radiant Control } \\
\text { AHU VSD Operation } \\
\text { Lighting Retrofit } \\
\text { Domestic Water Conservation }\end{array}$ & & & & & \\
\hline 6 & $\begin{array}{l}\text { Goodfellow Federal } \\
\text { Center }\end{array}$ & Overland MO & $\begin{array}{l}\text { Controls - Separate Lighting/HVAC } \\
\text { AHU Replacement } \\
\text { MUA } \\
\text { Boiler Initiative } \\
\text { IR/Split System - 122B to } 110 \\
\quad \text { Track Shed } \\
\text { Lighting } \\
\text { Building Envelope } \\
\text { AHU Sealing } \\
\text { AHU VFD } \\
\text { Transformers } \\
\text { Plumbing Fixtures } \\
\text { Ice Machine } \\
\text { Kitchen Sprayer }\end{array}$ & Trane & $\$ 9,121,413$ & 22 & 38,889 & $28 \%$ \\
\hline NCR & $\begin{array}{l}\text { Silver Spring/New } \\
\text { Carrollton }\end{array}$ & $\begin{array}{l}\text { Silver } \\
\text { Spring/Lanham } \\
\text { MD }\end{array}$ & $\begin{array}{l}\text { New Carrollton } \\
\text { Water Conservation } \\
\text { Building Envelope Improvements } \\
\text { Exhaust Air to OA Energy } \\
\text { Recovery } \\
\text { Kitchen Exhaust Controls } \\
\text { Electric \& Telephone Rm Cooling } \\
\text { System Upgrades } \\
\text { Silver Spring } \\
\text { Lighting Upgrades \& Advanced } \\
\text { Lighting Controls } \\
\text { Chilled Water Improvements } \\
\text { Ventilation Air System } \\
\text { Optimization }\end{array}$ & Ameresco & $\$ 44,633,045$ & 22 & 94,588 & $60 \%$ \\
\hline
\end{tabular}




\begin{tabular}{|c|c|c|c|c|c|c|c|c|}
\hline $\begin{array}{c}\text { GSA } \\
\text { Region }\end{array}$ & Building(s) & Location(s) & Conservation Measures & ESCO & Investment & $\begin{array}{c}\text { Term } \\
\text { (years) }\end{array}$ & $\begin{array}{c}\text { Energy } \\
\text { Savings } \\
\text { (MMBtu/yr) }\end{array}$ & $\begin{array}{c}\text { Percent } \\
\text { Energy } \\
\text { Savings }\end{array}$ \\
\hline
\end{tabular}

Building System Controls

Premium Efficiency Motors

Water Conservation

Building Envelope Improvements

High Efficiency Transformers 



\section{APPENDIX B. ESPC BEST PRACTICES}

One of GSA's innovations in the implementation of the NDER project was the establishment of the Project Management Office (PMO), the primary objective of which was to support the GSA Regional Offices during the ESPC award process. The PMO provided assistance in contracting, budgeting, financing, energy baselines and energy pricing, ECM pricing, and technical issues associated with the ECMs. Establishment of a uniform timeline for project award allowed GSA to reduce project award time (ESCO selection to award) by five months compared to the average award time for DOE's ESPC program.

Another objective of the PMO was to compile best practices for future ESPC efforts. The following list was compiled by Sharon Conger, the Program Manager of the PMO. The lessons are arranged in rough chronological order through the ESPC development process, from the initial notice of opportunity

1. In the NOO, include a statement allowing buildings to be added to the project.

a. Use Qualifications based down select rather than PA-based down-select as methodology.

b. Define the bundle of buildings that creates multiple task orders, in the NOO. Physical proximity helps with ESCO direct costs (supervision, safety inspections, etc.) during the construction phase.

2. For the PA Kickoff, discuss the purpose of the PA and the expectations. Recommend rough order of magnitude pricing with the objective of finding out if a project is viable. Additionally have the following information ready:

a. A description of the building and a photograph.

b. 2 -3 years of utility information - Actual utility bills are best and will speed up the process.

c. A utility release so the ESCO can obtain all utility nuance billing information directly from the utility. This should be on GSA Letterhead and have a space for the Contracting Officer (CO) or Project Manager (PM) phone number. Many utilities will not release the info until they check with the Government first.

d. Mechanical-Electrical-Plumbing (MEP) drawings as well as architectural drawings. GSA will need to know which buildings have Computer Aided Design (CAD) drawings for the cost estimating contract.

e. Security requirements.

f. Any prior energy studies (optional but encouraged).

g. Hazardous Materials report.

h. Identification of regional priority projects.

i. Information on recently completed and planned projects that could affect energy use in the building.

j. Operations and Maintenance $(O \& M)$ contract summary and what options the region is willing to entertain for O\&M from the ESCO, including O\&M savings.

k. Historic building information and parameters (Building Design Standards).

l. Include a pre-final draft of the TO-RFP - Indicate order of precedence of documents.

m. Discuss in PA Kickoff that submission presentations (if allowed) will only be for the regional project team and will not include other regional decision makers or national decision makers. Documents must fully reflect what reviewers need to know. 
n. Discuss the identification of subcontractors and how it relates to small business goals.

o. Allowable utility escalators (see below).

p. O\&M equipment list for the building.

q. Discuss lighting and water savings projects (and potentially other subs) on how competition will be achieved. Will a lighting study be required or will GSA allow ESCO criteria on selecting one vendor as was the case on the majority of the projects so far.

r. If the building is located on district chilled water or steam systems, a copy of the contract is needed.

s. Require acknowledgement of the interim Investment Grade Audit (IGA) submissions required in the TO-RFP.

t. If Courthouses are involved, identify if ESCOs should look at set backs in unoccupied Courtrooms/chambers or if that is not acceptable to the tenants.

3. Utility rate escalators - A determination on what escalators will be acceptable to the agency. The ESCOs default to the National institute of Standards and Technology (NIST) escalator which is higher than GSA will currently accept. These are owned by GSA National Energy Team and will be updated annually.

4. In the TO-RFP, indicate required submissions required in the IGA phase.

a. Recommend a limited 50 or $60 \%$ IGA submission to include for H.6.3 of the contract:

i. A. Project Overview including:

1. 1. Executive Summary.

2. 2.a - Site Description sub items a. i, ii, v, and vii.

3. 2 .b - Utility Summary sub items i - iii (should include agreed upon baseline).

ii. Volume I - Technical proposal.

1. 1 - ECM descriptions. including sub items $\mathrm{a}-\mathrm{m}$.

2. 3 - Management approach sub items b and c.

3. All savings calculations and assumptions should be provided at this point.

4. Cost for ECMs are expected to be within +/- $25 \%$.

iii. Volume II - Price Proposal - TO 1 - TO-4.

b. A full (90\%) IGA when pricing is complete - pre-negotiations.

c. $100 \%$ IGA which includes all correction and negotiated price changes.

d. Final Proposal IGA should only change to reflect the final interest rates.

5. Have cost estimator on board for the beginning of the IGA.

6. Establish a time frame for building walkthroughs, PA receipt and reviews upfront with ESCO and GSA teams.

7. Hold targeted weekly meetings that include a pre-set project agenda to ensure the IGA is on track. These need to include discussion on the ECMs being considered, not just logistics.

a. Target meetings for $\mathrm{M} \& \mathrm{~V}$ and a separate $\mathrm{M} \& \mathrm{~V}$ document to review after the meeting.

b. Target meeting for baseline review and discussion prior to first 50/60\% submission

8. Review Comment sheet - Keep a cohesive comment form throughout all reviews. Require ESCOs to indicate where a change is made in the source document in response to a comment.

9. In Negotiations discuss and document the following in the IGA:

a. Security Clearances delays are the responsibility of the ESCO.

b. Obtain estimated dates for needed Government Furnished Equipment for coordination 
with GSA.

c. In mechanical space and whereever practicable GSA should ensure that the ESCO conducts their own asbestos and lead-based paint survey and does not solely rely on the Government reports.

d. Ensure it is clear in the documents that when lighting systems are being replaced, that dimmer controls and any other existing conditions are replicated in the replacement.

e. Discuss the expectation that the schedule is to be controlled by the ESCO. Ensure the contract schedule accounts for adequate time for GSA reviews of submittals.

f. If lighting is being replaced or other measures such as PV are being pursued, ensure the ESCO and the GSA team includes an architect.

10. GSA Asbestos Policy requires an independent asbestos monitoring contract to be put in place prior to any abatement activity occurring. Regions need to plan and contract for this service.

11. For Contract Reviews:

a. Legal review of TO-RFP (at PA phase), and at award indicating business decisions made, focus legal on Risk and Responsibility (R\&R) matrix, etc.

b. For legal to be comfortable, include an "order of precedence” of contract documents. Best Practise: CO should have a briefing with legal to walk them through the documents.

c. Between pre-final and final, the TO-RFP needs to be conformed and sent to legal and contract review panel for review along with the IGA.

12. Financial Best Practices:

a. Based upon funding available, pay cost of IGA at time of award to avoid interest payments on the cost of the project development.

b. Identify any other appropriated funding as early as possible in the process to avoid reducing ECMs unnecessarily.

c. Rebates must be paid to GSA through the BA63 account. The amount guaranteed in the contract can be held and provided back to the region for the ESPC payment relating to the utility rebates and incentives.

d. Payment should be annual in advance to avoid additional interest.

e. Discuss changes in cost during construction period to determine the impact on financing. If deemed beneficial, statements requiring modifications of financing amount without penalty should be included.

13. Ensure that the teams understand the Governments' parameters in a design build project. Identify up front what submissions after award will be and what regions have the responsibility to review. 